\title{
Poliovirus vaccine strains detected in stool specimens of immunodeficient children in South Africa
}

\author{
Dobromir N. Pavlov, Walda B. Van Zyl, Mariane Kruger, Liezl Blignaut, Willie \\ O.K. Grabow and Marthie M. Ehlers
}

\begin{abstract}
After exposure to the oral poliovirus vaccine (OPV), immunocompetent persons excrete poliovirus (PV) vaccine strains for a limited period. In contrast, immunodeficient individuals remain sometimes chronically infected, and in some cases, PV excretion times as long as 10 years have been reported. During prolonged replication in the human intestine, the PV vaccine strain almost invariably reverts its attenuated character and acquires neurovirulent properties (vaccine-derived PVs, or VDPVs), which resemble wild-type PV strains. The aim of this study was to determine the occurrence of OPV strains in stools of immunodeficient children from a selected area in South Africa, as a first step toward future research on the prevalence and potential health impact of VDPVs. In a period of 1 year, a total of 164 stool samples of HIV-positive children aged 4 months to 8 years were studied for the excretion of OPV strains. In addition, 23 stool samples from healthy immunocompetent children were analyzed after receiving their OPV immunization. By applying a reverse transcription-polymerase chain reaction in combination with a nested PCR, a total of 54 enteroviruses (EVs) were detected in the stool specimens of the immunodeficient children. Using restriction enzyme analysis, 13 PVs were distinguished from 41 nonpolio EVs (NPEVs). A Sabin-specific RT-triplex PCR confirmed the presence of 7 Sabin PV type 1, 4 Sabin PV type 3, and 2 Sabin PV type 2 isolates. The majority of the NPEV group was made up of 7 coxsackievirus B3 (CBV3), 6 echovirus 11 (ECV11), 5 ECV9, and 3 coxsackievirus A6 (CAV6) isolates. According to the results, two of the immunodeficient patients (P023 and P140) who had received their last OPV immunization more than 15 months before (vaccinated at 14 weeks of age) tested positive for Sabin PVs types 3 and 1, respectively. A 5-year-old immunodeficient patient (P052) who had received her last OPV immunization more than 42 months before (vaccinated at 18 months of age) tested positive for Sabin PV type 1. These results suggested that immunodeficient patients vaccinated with OPV might excrete potentially pathogenic VDPVs for a prolonged period. These VDPVs may circulate in the community, resulting in possible infections in the unvaccinated population. Therefore, the information obtained in this study would be essential for strategies aimed at the protection of both immunodeficient as well as immunocompetent individuals against complications of vaccination with OPV.
\end{abstract}




\section{Article Outline}

1. Introduction

2. Materials and methods

2.1. PV stock

2.2. Sample size

2.3. Patient specimens

2.4. Extraction of the RNA

2.5. Reverse transcription-polymerase chain reaction

2.6. Nested polymerase chain reaction

2.7. Reverse transcription multiplex PCR to distinguish PVs from nonpolio EVs

2.8. Restriction enzyme analysis

2.9. Sabin-specific RT-triplex PCR

2.10. Quality control of the amplification methods

3. Results and discussion

4. Conclusion

References

\section{Introduction}

Poliovirus (PV) is the only enterovirus (EV) for which a vaccine is available (Zaoutis and Klein, 1998). Two vaccines were developed to control poliomyelitis: the inactivated PV vaccine (IPV) and the oral PV vaccine (OPV) (Wood et al., 2000). Although the merits of the 2 different types of polio vaccines have been the subject of heated debates, both of them were highly effective in eradicating polio from the Western hemisphere and in decreasing the incidence of poliomyelitis worldwide (Minor, 1999 and Wood and Thorley, 2003). The introduction of the IPV reduced the number of cases by $90 \%$, and this decline continued after the introduction of the OPV during the early 1960s (Minor, 1999 and Wood et al., 2000). The recent declaration of 3 major regions of the world, the Americas, Europe, and the western Pacific, as being free of circulating wild-type PV constitutes a major achievement in public health (Wood and Thorley, 2003).

Previously, no long-term carrier stage in humans has been reported after wild-type PV infection (Wood et al., 2000 and Hovi et al., 2004). In paralytic cases caused by the wildtype PV, virus titers in feces rapidly decrease during the few weeks after onset of disease (Alexander et al., 1997 and Hovi et al., 2004). However, Hovi et al. (2004) have reported prolonged excretion of wild-type PV for 7 months by 2 immigrant siblings in Finland (Hovi et al., 2004). In immunocompetent OPV recipients, the excretion of PVs is usually short-lived, seldom exceeding 2 months (Alexander et al., 1997, Kew et al., 1998, Wood et al., 2000 and Hovi et al., 2004). In contrast, several OPV recipients with severe deficiencies in humoral immunity tend to remain chronically infected and have been reported to excrete PVs for long periods (in some cases, as long as 10 years) (Kew et al., 1998, Bellmunt et al., 1999 and Shulman et al., 2000). 
During prolonged replication in the human intestine, the OPV strain invariably reverts its attenuated character and acquires neurovirulent properties as well as transmissibility characteristics typical of wild-type PV strains (Buttinelli et al., 2003 and Hovi et al., 2004). Reversion of the OPV strains to increased neurovirulence is one key factor for the occurrence of vaccine-associated paralytic poliomyelitis (VAPP) (Sutter and Prevots, 1994, Bellmunt et al., 1999, Shulman et al., 2000 and Hovi et al., 2004). As a consequence, chronically infected individuals may present with paralytic disease some years after OPV administration and may also transmit vaccine-derived PVs (VDPVs) to their close contacts (Kew et al., 1998, Bellmunt et al., 1999, Hovi et al., 2004 and Yang et al., 2003). This raises concerns for the desired future global cessation of OPV immunization, which will be considered after the eradication program has been completed (Hovi et al., 2004).

Patients with primary immunodeficiency disorders affecting the B-cell system appear to be at highest risk for prolonged PV replication and excretion (World Health Organization Scientific Group, 1997 and Wood et al., 2000). This group includes people with either Xlinked or sporadic agammaglobulinemia and those with common variable immunodeficiency (World Health Organization Scientific Group, 1997 and Wood et al., 2000). There are very limited data on secondary immunodeficiency as a risk factor for VAPP or prolonged VDPV excretion (Centers for Disease Control and Prevention, 1997 and Wood et al., 2000). According to current scientific data, human immunodeficiency virus (HIV) infection is not a risk factor for paralytic poliomyelitis caused by wild-type PV or VDPV (Wood et al., 2000). However, two case reports, one from Romania and one from Zimbabwe, have linked HIV infection and VAPP (Ion-Neldescu et al., 1994, Chitsike and van Furth, 1999 and Wood et al., 2000). The OPV is therefore not advisable for immunodeficient people (Minor, 2001 and Buttinelli et al., 2003). Although immunodeficiencies are listed as a contraindication for receiving OPV, patients with these clinical conditions may receive the OPV before their immunodeficiency is diagnosed or may be infected with OPV strains excreted by other vaccinees or due to circulating OPV strains within the community (person-to-person transmission) (Triki et al., 2003).

In the current study, various molecular techniques were applied to determine the presence of OPV strains in stool specimens of immunodeficient patients (such as HIV-positive children) from a selected area in South Africa. In a follow-up study, the genomes of these OPV strains will be sequenced to find mutations leading to the reversion of the OPV strains to increased neurovirulence.

\section{Materials and methods}

\subsection{PV stock}

PV controls included: PV types 1, 2, and 3 vaccine strains, which were clinical isolates obtained from the National Institute of Virology, Johannesburg, South Africa. These PVs were recovered in HEp-2 cells (human epidermoid carcinoma) (Code ATCC CCL-23, passage 350-365) (Manor et al., 1999a, Manor et al., 1999b and Buttinelli et al., 2003). 
The cell cultures were frozen and thawed 3 times after demonstrating a cytopathogenic effect. The debris was removed by centrifugation at $600 \times g$ (Eppendorf Centrifuge $5402 \mathrm{D}$, Hamburg, Germany) for $10 \mathrm{~min}$ at room temperature $\left( \pm 25^{\circ} \mathrm{C}\right)$. The PV suspensions were stored at $-70{ }^{\circ} \mathrm{C}$ for further analysis.

\subsection{Sample size}

To estimate the prevalence of OPV strains (possibly VDPVs) in the stool specimens of immunodeficient children, a maximum sample size associated with an expected prevalence of $50 \%$ was analyzed. Statistically, a sample size of 162 stool specimens of immunodeficient children was studied to achieve a confidence level of $80 \%$ and the prevalence was estimated to an accuracy of $5 \%$.

\subsection{Patient specimens}

In a period of 1 year (2003-2004), one stool specimen was collected from each of the 164 HIV-positive children (including those with an AIDS indicator condition according to the CDC classification) from the Department of Paediatrics, Kalafong Hospital/University of Pretoria. The vaccination history of these children revealed that all of them had previously been immunized with OPV (Table 2). Based on this CDC classification, 3 clinical categories of HIV disease can be distinguished, namely, $\mathrm{A}=$ documented asymptomatic HIV infection; $\mathrm{B}=$ symptomatic HIV infection, and $\mathrm{C}=$ symptomatic HIV infection with an AIDS indicator condition. In the case of A1, B1, and C1 infections, the patient would have a $\mathrm{CD} 4{ }^{+}$count of $>500$ cells $/ \mathrm{mm}^{3}$ or $\mathrm{CD} 4^{+}$cell percentage of $>28 \%$. In the case of A2, B2, and C2 infections, the patient would have a CD4 ${ }^{+}$count of 200-499 cells $/ \mathrm{mm}^{3}$ or $\mathrm{CD}^{+}$percentage of $14-28 \%$, and in $\mathrm{A} 3, \mathrm{~B} 3, \mathrm{C} 3$ infections, the patient would have a $\mathrm{CD} 4^{+}$count of $<200$ cells $/ \mathrm{mm}^{3}$ or $\mathrm{CD} 4^{+}$cell percentage of $<14 \%$. The immunodeficient children were between the ages of 4 months to 8 years and were hospitalized for various diseases such as bronchopneumonia, cardiomyopathy, encephalopathy, gastroenteritis, herpes stomatitis, lymphocytic intestinal pneumonia, meningitis, miliary tuberculosis, Pneumocystis carinii pneumonia (Pneumocystis jiroveci), pulmonary tuberculosis, pneumonia, septicemia, and upper respiratory tract infections. In total, 17 of these immunodeficient children died during the course of the study, therefore, the excretion of EVs by these patients could not be followed.

During the same period, 23 stool samples from 3 healthy immunocompetent babies were collected after receiving their scheduled OPV immunizations. This group of children served as a control group to demonstrate the type of PVs being excreted and possibly the duration of excretion of OPV strains by immunocompetent children. The stool samples were collected regularly from the immunocompetent children during their OPV immunization schedule: 1 stool specimen $48 \mathrm{~h}$ after each vaccination (at birth, 6, 10, and 14 weeks, and 18 months) and then 1 stool sample on a weekly basis until no PV was detected in the stools. 


\subsection{Extraction of the RNA}

Stool specimens were homogenized and clarified by mixing $300 \mu \mathrm{L}$ of $10-50 \%$ fecal suspension with an equal volume of freon (Sigma, St. Louis, MO), and the mixture was centrifuged at $12000 \times g$ (Eppendorf Centrifuge 5402D) for $5 \mathrm{~min}$ at room temperature $\left( \pm 25^{\circ} \mathrm{C}\right)$. A total of $140 \mu \mathrm{L}$ of the supernatant was mixed with $500 \mu \mathrm{L}$ of TRIzol

(Invitrogen Life Techno, Paisley, Scotland) and incubated at room temperature $\left( \pm 25^{\circ} \mathrm{C}\right)$ for $5 \mathrm{~min}$ to permit complete dissociation of the nucleoprotein complex for the extraction of viral RNA according to the manufacturer's instructions. Following the addition of pure chloroform $(100 \mu \mathrm{L})($ Sigma), each mixture was centrifuged at $12000 \times g$ (Eppendorf Centrifuge 5402D) for $15 \mathrm{~min}$ at $4{ }^{\circ} \mathrm{C}$. The aqueous phase $(300 \mu \mathrm{L})$ was transferred to sterile Eppendorf tubes containing $30 \mu \mathrm{L}$ of sodium acetate ( $\mathrm{pH}$ 5.2) (Merck, Darmstadt, Germany) and $600 \mu \mathrm{L}$ of $100 \%$ ethanol (Merck). After $24 \mathrm{~h}$ at $-20{ }^{\circ} \mathrm{C}$, the samples were centrifuged at $12000 \times g$ (Eppendorf Centrifuge 5402D) for 15 min at $4{ }^{\circ} \mathrm{C}$. Each RNA pellet was washed with $300 \mu \mathrm{L}$ of $70 \%$ ethanol (Merck) and centrifuged at $12000 \times g$ (Eppendorf Centrifuge 5402D) for $5 \mathrm{~min}$ at $4{ }^{\circ} \mathrm{C}$. The pellets were briefly air-dried and dissolved in $35 \mu \mathrm{L}$ of RNase-free water (DEPC water, Promega, Madison, WI). The dissolved pellets were incubated for $10 \mathrm{~min}$ at $42{ }^{\circ} \mathrm{C}$ in a hybridization oven (Techne Hybridiser HB-1D, Techne, Cambridge, UK). The extracted RNA was frozen at $-70{ }^{\circ} \mathrm{C}$ for further analysis.

\subsection{Reverse transcription-polymerase chain reaction}

The reverse transcription-polymerase chain reaction (RT-PCR) for the amplification of RNA was carried out using a Promega Access RT-PCR system (Promega) as described by Gow et al. (1991). Optimized final concentrations in a total volume of $50 \mu \mathrm{L}$ included $\mathrm{AMV} / \mathrm{Tfl}$ reaction buffer $(1 \times), 1.5 \mathrm{mmol} / \mathrm{L} \mathrm{MgSO}_{4}$, dNTP mix (final concentration of 0.2 $\mathrm{mmol} / \mathrm{L}$ ), 50 pmol each of primers EP1, and EP4 (Sigma-Genosys, Pampisford, Cambridgeshire, UK) (Table 1), 5 U each of AMV reverse transcriptase and Tfl DNA polymerase (Promega). A total of $10 \mu \mathrm{L}$ of RNA was added to each PCR reaction. The PCR conditions included reverse transcription for $45 \mathrm{~min}$ at $48^{\circ} \mathrm{C}$ (DNA denaturation for $1 \mathrm{~min}$ at $94{ }^{\circ} \mathrm{C}$, primer annealing for $1 \mathrm{~min}$ at $56^{\circ} \mathrm{C}$, and primer extension for $1 \mathrm{~min}$ at 72 ${ }^{\circ} \mathrm{C}$ ), 30 cycles, and final extension for $10 \mathrm{~min}$ at $72{ }^{\circ} \mathrm{C}$ (Hybaid OmniGene Thermocycler, Ashford, UK). After 30 cycles, $20 \mu \mathrm{L}$ of each PCR product were subjected to agarose (2\%) (Seakem LE agarose, Bioproducts BioWhittaker, Walkersville, ME) gel electrophoresis (Midicell Primo Gel Apparatus, Holbrook, NY). 
Table 1.

Primers used in the detection and characterization of PVs

\begin{tabular}{|c|c|c|c|c|}
\hline $\begin{array}{l}\text { Primer } \\
\text { region and } \\
\text { map position }\end{array}$ & $\begin{array}{l}\text { Pri- } \\
\text { mer }\end{array}$ & Sequence $^{a}$ & $\begin{array}{l}\text { Amp } \\
\text { licon } \\
\text { lengt } \\
\text { h } \\
\text { (bp) }\end{array}$ & $\begin{array}{l}\text { Speci- } \\
\text { ficity }\end{array}$ \\
\hline $65-84$ & EP1 & 5'-CGG TAC CTT TGT GCG CCT GT-3' & 408 & EV \\
\hline $454-473$ & EP4 & 5'-TTA GGA TTA GCC GCA TTC AG-3' & & \\
\hline $163-178$ & E1 & 5'-AAG CAC TTC TGT TTC C-3' & 297 & EV \\
\hline $443-460$ & E2 & 5'-CAT TCA GGG GCC GGA GGA-3' & & EV \\
\hline $4460-4478$ & Po1 & 5'-CAG TTC AAG AGC AA $(\underline{\mathrm{A}} / \mathrm{G})$ CAC C-3' & 193 & PV \\
\hline $4634-4653$ & Po2 & $\begin{array}{l}5^{\prime}-\mathrm{TC}(\mathrm{A} / \underline{\mathrm{G}}) \mathrm{TCC} \text { AT }(\underline{\mathrm{A} / \mathrm{G}}) \mathrm{AT}(\mathrm{A} / \underline{\mathrm{C}}) \mathrm{AC} \\
(\mathrm{T} / \underline{\mathrm{C}}) \mathrm{AC}(\underline{\mathrm{T}} / \mathrm{A}) \mathrm{CC}-3^{\prime}\end{array}$ & & PV \\
\hline $4922-4941$ & Po3 & 5'-GAA ATG TGT AAG AAC TGT CA-3' & 565 & PV \\
\hline $5467-5487$ & Po4 & 5'-GTA ACA ATG TTT CTT TTA GCC-3' & & PV \\
\hline $2584-2601$ & $\mathrm{~S} 1-1$ & 5'-TCC ACT GGC TTC AGT GTT-3' & 97 & $\begin{array}{l}\text { Sabin PV } \\
\text { type } 1\end{array}$ \\
\hline $2505-2523$ & $\mathrm{~S} 1-2$ & 5'-AGG TCA GAT GCT TGA AAG C-3' & & \\
\hline $2580-2595$ & $\mathrm{~S} 2-1$ & 5'-CGG CTT GTG TCC AGG C-3' & 71 & $\begin{array}{l}\text { Sabin PV } \\
\text { type } 2\end{array}$ \\
\hline \multirow[t]{2}{*}{$2525-2544$} & $\mathrm{~S} 2-2$ & 5'-CCG TTG AAG GGA TTA CTA AA-3' & & \\
\hline & S3-1a & 5'-AGT ATC AGG TAA GCT ATC C-3' & 54 & $\begin{array}{l}\text { Sabin PV } \\
\text { type } 3\end{array}$ \\
\hline $2537-2553$ & S3-2 & 5'-AGG GCG CCC TAA CTT TG-3' & & \\
\hline
\end{tabular}

${ }^{\mathrm{a}}$ For the degenerate primers Po1 and Po2, the sequence of the Sabin strain is underlined. 


\subsection{Nested polymerase chain reaction}

A second PCR (nested) run was undertaken as described by Kuan (1997), in which $1 \mu \mathrm{L}$ of the amplified RT-PCR product was added to $49 \mu \mathrm{L}$ of previously prepared PCR mixture (Promega). The PCR mixture contained the following: $1 \times$ PCR buffer $(10$ $\mathrm{mmol} / \mathrm{L}$ Tris-HCl, $\mathrm{pH} 9 ; 50 \mathrm{mmol} / \mathrm{L} \mathrm{KCl} ; 0.1 \%$ Triton $\mathrm{X}-100$ ), $\mathrm{MgCl}_{2}$ (final concentration of $1.5 \mathrm{mmol} / \mathrm{L}$ ), dNTP mix (final concentration of $0.2 \mathrm{mmol} / \mathrm{L}$ ), $50 \mathrm{pmol}$ each of primers E1 and E2 (Sigma-Genosys) (Table 1), and 1.5 U of Taq DNA polymerase. The PCR conditions included DNA denaturation for $3 \mathrm{~min}$ at $94{ }^{\circ} \mathrm{C}$ (DNA denaturation for $1 \mathrm{~min}$ at $94{ }^{\circ} \mathrm{C}$, primer annealing for $1 \mathrm{~min}$ at $45^{\circ} \mathrm{C}$, and primer extension for $1 \mathrm{~min}$ at $72{ }^{\circ} \mathrm{C}$ ), 30 cycles, and final extension for $10 \mathrm{~min}$ at $72{ }^{\circ} \mathrm{C}$ (Hybaid OmniGene Thermocycler). After 30 cycles, $20 \mu \mathrm{L}$ of each PCR product were subjected to $2 \%$ agarose gel electrophoresis (Midicell Primo Gel Apparatus).

\subsection{Reverse transcription multiplex PCR to distinguish PVs from nonpolio EVs}

A reverse transcription multiplex PCR (RT-multiplex PCR) as described by Egger et al. (1995) was used for the rapid detection and distinction of PVs from nonpolio EVs (NPEVs). Primers specific for either EV or PV were combined in a RT-multiplex PCR (Promega) to obtain amplicons of different sizes (Table 1). Optimized final concentrations in a total volume of $50 \mu \mathrm{L}$ were as follows: AMV/Tfl reaction buffer $(1 \times)$, $2.0 \mathrm{mmol} / \mathrm{L} \mathrm{MgSO}_{4}$, dNTP Mix (final concentration of $0.2 \mathrm{mmol} / \mathrm{L}$ ), $25 \mathrm{pmol}$ each of primers E1, E2, Po1, Po2, Po3, and Po4 (Sigma-Genosys), and 5 U each of AMV reverse transcriptase and $T f l$ DNA polymerase (Promega). A total of $10 \mu \mathrm{L}$ of RNA was added to each PCR reaction. The PCR conditions included reverse transcription for $45 \mathrm{~min}$ at 48 ${ }^{\circ} \mathrm{C}$ (DNA denaturation for $1 \mathrm{~min}$ at $94{ }^{\circ} \mathrm{C}$, primer annealing for $1.5 \mathrm{~min}$ at $45{ }^{\circ} \mathrm{C}$, and primer extension for $1 \mathrm{~min}$ at $72{ }^{\circ} \mathrm{C}$ ), 30 cycles, and final extension for $10 \mathrm{~min}$ at $72{ }^{\circ} \mathrm{C}$ (Hybaid OmniGene Thermocycler).

\subsection{Restriction enzyme analysis}

EVs were partially typed with restriction enzymes (REs) such as StyI, BglI, and XmnI (Promega) (Kämmerer et al., 1994 and Kuan, 1997). Aliquots of $10 \mu \mathrm{L}$ of the nested PCR products were incubated with $10 \mathrm{U}$ of the REs in a $30-\mu \mathrm{L}$ reaction volume with the buffer recommended by the manufacturer. Samples were incubated for $3 \mathrm{~h}$ at $37^{\circ} \mathrm{C}$ and were analyzed using 7\% polyacrylamide (BioRad, Hercules, CA) gel-electrophoresis (Hoefer, San Francisco, CA). The restriction patterns of the EVs were evaluated based on previously published RE patterns (Kämmerer et al., 1994 and Kuan, 1997).

\subsection{Sabin-specific RT-triplex PCR}

Three sets of primers specific for Sabin PV types 1 to 3 were combined in a Sabinspecific RT-triplex PCR to confirm the isolated PVs as OPV strains based on the production of amplicons of specific sizes (Table 1) (Yang et al., 1991 and Yang et al., 1992). A $50 \mu \mathrm{L}$ reaction volume was prepared using: AMV/Tfl Reaction Buffer $(1 \times)$, dNTP Mix (final concentration of $0.2 \mathrm{mmol} / \mathrm{L}$ ), 25 pmol each of primers S1-1, S1-2, S2- 
1, S2-2, S3-1a, S3-2 (Sigma-Genosys), $1.5 \mathrm{mmol} / \mathrm{L}$ of $\mathrm{MgSO}_{4}$, and $5 \mathrm{U}$ of AMV reverse transcriptase as well as $T f l$ DNA polymerase (Promega). A total of $10 \mu \mathrm{L}$ of RNA was added to each PCR reaction. The PCR conditions included: reverse transcription for 45 min at $42{ }^{\circ} \mathrm{C}$ (DNA denaturation for $30 \mathrm{~s}$ at $95{ }^{\circ} \mathrm{C}$, primer annealing for $45 \mathrm{~s}$ at $56{ }^{\circ} \mathrm{C}$, and primer extension for $1 \mathrm{~min}$ at $72{ }^{\circ} \mathrm{C}$ ), 30 cycles, and final extension for $10 \mathrm{~min}$ at 72 ${ }^{\circ} \mathrm{C}$ (Hybaid OmniGene Thermocycler). The amplified products $(20 \mu \mathrm{L})$ were separated using 7\% polyacrylamide (BioRad) gel electrophoresis using a Hoefer electrophoresis unit at $120 \mathrm{~V}$.

\subsection{Quality control of the amplification methods}

Standard precautions were applied in all the manipulations to reduce the possibility of sample contamination by amplified DNA molecules. Separate laboratories were used for reagents, treatment of samples, and manipulation of amplified fragments. Negative controls for RNA extraction and RT-PCRs were included in each assay.

\section{Results and discussion}

A RT-multiplex PCR has been developed for the rapid and sensitive detection of PVs (Egger et al., 1995). This RT-multiplex PCR has been applied in the discrimination of PVs from NPEVs, which is an important factor in the PV surveillance program (Egger et al., 1995). This is achieved by combining EV-specific primers (E1 and E2) and PVspecific primers (Po1 to Po4), thus giving rise to amplicons of specific sizes (Table 1) (Egger et al., 1995). In this study, the sensitivity of the RT-multiplex PCR, as measured with RNA extracted from a virus suspension, was found to be $10^{2}$ plaque forming units of PV type 1 in $140 \mu \mathrm{L}$ of sample, and these results were in agreement with reports by other researchers such as Egger et al. (1995), Melnick (1996), and Vivier et al. (2001). However, in this study, the RT-multiplex PCR generally failed to detect the majority of PVs and EVs being excreted by the immunodeficient as well as immunocompetent children. This outcome could be attributed in part to the components of the stool specimens that inhibit the PCR reaction. Since the RT-multiplex PCR includes 1-step RT-PCR without a nested PCR, this method may not be sensitive enough to detect the presence of a low number of PVs and EVs in stool specimens.

To avoid false-negative results, a RT-PCR in combination with a nested PCR was applied in the current study. This method is very sensitive, and wild-type PV sequences could still be picked up if they circulated anywhere in the world (Kämmerer et al., 1994, Kuan, 1997 and Vivier et al., 2001). In this study, 54 EVs were detected in the stool specimens of the 164 HIV-positive children. The detection of EVs in the feces of the immunodeficient children did not completely confirm an EV diagnosis, because the excretion of EVs may persist for several weeks after an EV infection in some patients (Zaoutis and Klein, 1998).

Based on the RE analysis, 13 PVs were successfully distinguished from 41 NPEVs. These 13 PVs were identified as 7 PV type 1 (53.8\%), 4 PV type $3(30.8 \%)$, and 2 PV type $2(15.4 \%)$ isolates (Table 2). Using the Sabin-specific RT-triplex PCR, all of these 
PV isolates were typed as Sabin PV vaccine strains. No wild-type PVs were detected in the stool samples, which was in agreement with epidemiological data indicating that the last case of polio associated with wild-type PV in South Africa was in 1989 (CDC, 2003). None of the other EV prototype strains amplified with the Sabin-specific primers.

Table 2.

$\mathrm{PV}$ vaccine strains isolated from stool specimens of immunodeficient children from a selected area in South Africa

\begin{tabular}{|c|c|c|c|c|c|c|c|}
\hline $\begin{array}{l}\text { Pa- } \\
\text { tient } \\
\text { num } \\
\text { ber }\end{array}$ & $\begin{array}{l}\text { Gen } \\
\text { der }\end{array}$ & $\begin{array}{l}\text { Clinical } \\
\text { condi- } \\
\text { tion }\end{array}$ & Date of birth & $\begin{array}{l}\text { Polio } \\
\text { immuni- } \\
\text { zation }\end{array}$ & $\begin{array}{l}\text { Stool } \\
\text { specimens } \\
\text { collected }\end{array}$ & $\begin{array}{l}\text { Typ } \\
\text { e of } \\
\text { vi- } \\
\text { rus }\end{array}$ & $\begin{array}{l}\text { CDC } \\
\text { classification }\end{array}$ \\
\hline P020 & Male & PCP died & $10 / 03 / 2003$ & $10 / 03 / 2003$ & $29 / 07 / 2003$ & PV1 & $\mathrm{C} 3$ \\
\hline $\begin{array}{l}2385 \\
048\end{array}$ & & & & $23 / 04 / 2003$ & & & $\begin{array}{l}\mathrm{CD} 4^{+} \text {count of } \\
<200 \\
\text { cells } / \mathrm{mm}^{3}\end{array}$ \\
\hline P023 & Male & $\begin{array}{l}\text { Encepha- } \\
\text { lopathy }\end{array}$ & $01 / 2002$ & $01 / 2002$ & $29 / 07 / 2003$ & PV3 & $\mathrm{C} 2$ \\
\hline \multirow[t]{3}{*}{$\begin{array}{l}2379 \\
238\end{array}$} & & $\mathrm{G} / \mathrm{E}$ & & $02 / 2002$ & & & $\begin{array}{l}\mathrm{CD}^{+} \text {count of } \\
200-499 \\
\text { cells } / \mathrm{mm}^{3}\end{array}$ \\
\hline & & РTB & & $03 / 2002$ & & & \\
\hline & & & & $04 / 2002$ & & & \\
\hline P025 & $\begin{array}{l}\text { Fem } \\
\text { ale }\end{array}$ & $\begin{array}{l}\text { Herpes } \\
\text { stomatitis }\end{array}$ & $14 / 01 / 2002$ & $14 / 01 / 2002$ & 29/07/2003 & PV3 & B2 \\
\hline \multirow[t]{4}{*}{$\begin{array}{l}2330 \\
375\end{array}$} & & $\begin{array}{l}\text { Pneu- } \\
\text { monia }\end{array}$ & & $26 / 02 / 2002$ & & & $\begin{array}{l}\mathrm{CD} 4^{+} \text {count of } \\
200-499 \\
\text { cells } / \mathrm{mm}^{3}\end{array}$ \\
\hline & & & & $25 / 03 / 2002$ & & & \\
\hline & & & & $24 / 04 / 2002$ & & & \\
\hline & & & & $16 / 07 / 2003$ & & & \\
\hline P031 & Male & $\begin{array}{l}\text { Menin- } \\
\text { gitis }\end{array}$ & $02 / 05 / 2003$ & $02 / 05 / 2003$ & $29 / 07 / 2003$ & PV2 & B \\
\hline 2374 & & & & $13 / 06 / 2003$ & & & \\
\hline
\end{tabular}




\begin{tabular}{|c|c|c|c|c|c|c|c|}
\hline $\begin{array}{l}\text { Pa- } \\
\text { tient } \\
\text { num } \\
\text { ber }\end{array}$ & $\begin{array}{l}\text { Gen } \\
\text { der }\end{array}$ & $\begin{array}{l}\text { Clinical } \\
\text { condi- } \\
\text { tion }\end{array}$ & Date of birth & $\begin{array}{l}\text { Polio } \\
\text { immuni- } \\
\text { zation }\end{array}$ & $\begin{array}{l}\text { Stool } \\
\text { specimens } \\
\text { collected }\end{array}$ & $\begin{array}{l}\text { Typ } \\
\text { e of } \\
\text { vi- } \\
\text { rus }\end{array}$ & $\begin{array}{l}\text { CDC } \\
\text { classification }\end{array}$ \\
\hline \multicolumn{8}{|l|}{125} \\
\hline P039 & $\begin{array}{l}\text { Fem } \\
\text { ale }\end{array}$ & BPN & $15 / 05 / 2003$ & $16 / 05 / 2003$ & $19 / 08 / 2003$ & PV2 & B1 \\
\hline $\begin{array}{l}2388 \\
823\end{array}$ & & & & $27 / 06 / 2003$ & & & $\begin{array}{l}\mathrm{CD} 4^{+} \text {count of } \\
>500 \\
\text { cells } / \mathrm{mm}^{3}\end{array}$ \\
\hline P045 & Male & $\begin{array}{l}\text { Pneu- } \\
\text { monia }\end{array}$ & $10 / 06 / 2003$ & $10 / 06 / 2003$ & $22 / 08 / 2003$ & PV3 & B2 \\
\hline $\begin{array}{l}2389 \\
052\end{array}$ & & & & $22 / 07 / 2003$ & $21 / 10 / 2003$ & $\mathrm{NG}$ & $\begin{array}{l}\mathrm{CD}^{+} \text {count of } \\
200-499 \\
\text { cells } / \mathrm{mm}^{3}\end{array}$ \\
\hline P052 & $\begin{array}{l}\text { Fem } \\
\text { ale }\end{array}$ & $\begin{array}{l}\text { Miliary } \\
\text { TB }\end{array}$ & $26 / 09 / 1998$ & $26 / 09 / 1998$ & $04 / 09 / 2003$ & PV1 & $\mathrm{C} 3$ \\
\hline \multirow[t]{4}{*}{$\begin{array}{l}2391 \\
424\end{array}$} & & & & 07/11/1998 & & & $\begin{array}{l}\mathrm{CD}^{+} \text {count of } \\
<200 \\
\text { cells } / \mathrm{mm}^{3}\end{array}$ \\
\hline & & & & $05 / 12 / 1998$ & & & \\
\hline & & & & 02/01/1999 & & & \\
\hline & & & & $27 / 03 / 2000$ & & & \\
\hline P069 & Male & $\begin{array}{l}\text { Pneu- } \\
\text { monia }\end{array}$ & $07 / 08 / 2003$ & $07 / 08 / 2003$ & $10 / 10 / 2003$ & PV1 & B \\
\hline $\begin{array}{l}2386 \\
771\end{array}$ & & & & $18 / 09 / 2003$ & & & \\
\hline P085 & $\begin{array}{l}\text { Fem } \\
\text { ale }\end{array}$ & $\begin{array}{l}\text { Maras- } \\
\text { mic } \\
\text { pneu- } \\
\text { monia }\end{array}$ & $23 / 10 / 2002$ & $24 / 10 / 2002$ & $23 / 10 / 2003$ & PV1 & B3 \\
\hline $\begin{array}{l}2400 \\
161\end{array}$ & & & & $03 / 12 / 2002$ & & & $\begin{array}{l}\mathrm{CD}^{+} \text {count of } \\
<200 \\
\text { cells } / \mathrm{mm}^{3}\end{array}$ \\
\hline
\end{tabular}




\begin{tabular}{|c|c|c|c|c|c|c|c|}
\hline $\begin{array}{l}\text { Pa- } \\
\text { tient } \\
\text { num } \\
\text { ber }\end{array}$ & $\begin{array}{l}\text { Gen } \\
\text { der }\end{array}$ & $\begin{array}{l}\text { Clinical } \\
\text { condi- } \\
\text { tion }\end{array}$ & Date of birth & $\begin{array}{l}\text { Polio } \\
\text { immuni- } \\
\text { zation }\end{array}$ & $\begin{array}{l}\text { Stool } \\
\text { specimens } \\
\text { collected }\end{array}$ & $\begin{array}{l}\text { Typ } \\
\text { e of } \\
\text { vi- } \\
\text { rus }\end{array}$ & $\begin{array}{l}\text { CDC } \\
\text { classification }\end{array}$ \\
\hline & & & & $23 / 01 / 2003$ & & & \\
\hline & & & & $12 / 03 / 2003$ & & & \\
\hline P095 & Male & $\begin{array}{l}\text { Chronic } \\
\text { diarrhea }\end{array}$ & $13 / 08 / 2001$ & $15 / 08 / 2001$ & $01 / 10 / 2003$ & PV1 & $\mathrm{C} 3$ \\
\hline \multirow[t]{4}{*}{$\begin{array}{l}2353 \\
775\end{array}$} & & & & $27 / 09 / 2001$ & & & $\begin{array}{l}\mathrm{CD}^{+} \text {count of } \\
<200 \\
\text { cells } / \mathrm{mm}^{3}\end{array}$ \\
\hline & & & & $15 / 11 / 2001$ & & & \\
\hline & & & & $29 / 01 / 2002$ & & & \\
\hline & & & & $18 / 02 / 2003$ & & & \\
\hline P114 & Male & $\mathrm{G} / \mathrm{E}$ & 25/05/2003 & $26 / 05 / 2003$ & $01 / 12 / 2003$ & PV1 & B3 \\
\hline \multirow[t]{3}{*}{$\begin{array}{l}2404 \\
862\end{array}$} & & $\begin{array}{l}\text { Dehydra- } \\
\text { tion }\end{array}$ & & $07 / 07 / 2003$ & & & $\begin{array}{l}\mathrm{CD}^{+}{ }^{+} \text {count of } \\
<200 \\
\text { cells } / \mathrm{mm}^{3}\end{array}$ \\
\hline & & & & $05 / 08 / 2003$ & & & \\
\hline & & & & $02 / 09 / 2003$ & & & \\
\hline P126 & $\begin{array}{l}\mathrm{Fe}- \\
\text { male }\end{array}$ & $\mathrm{G} / \mathrm{E}$ & $12 / 04 / 2002$ & $12 / 04 / 2002$ & $17 / 12 / 2003$ & PV3 & A3 \\
\hline \multirow[t]{4}{*}{$\begin{array}{l}2369 \\
107\end{array}$} & & $\begin{array}{l}\text { Dehy- } \\
\text { dration }\end{array}$ & & $22 / 05 / 2002$ & & & $\begin{array}{l}\mathrm{CD}^{+}{ }^{+} \text {count of } \\
<200 \\
\text { cells } / \mathrm{mm}^{3}\end{array}$ \\
\hline & & & & $19 / 06 / 2002$ & & & \\
\hline & & & & $17 / 07 / 2002$ & & & \\
\hline & & & & 08/10/2003 & & & \\
\hline P140 & Male & $\begin{array}{l}\text { Pneu- } \\
\text { monia }\end{array}$ & 06/05/2002 & $06 / 05 / 2002$ & $02 / 01 / 2004$ & PV1 & B2 \\
\hline $\begin{array}{l}2332 \\
025\end{array}$ & & & & $19 / 06 / 2002$ & & & $\begin{array}{l}\text { CD4 }{ }^{+} \text {count of } \\
200-499 \text { - }\end{array}$ \\
\hline
\end{tabular}




\begin{tabular}{|l|l|l|l|l|l|l|l|}
\hline $\begin{array}{l}\text { Pa- } \\
\text { tient } \\
\text { num } \\
\text { ber }\end{array}$ & $\begin{array}{l}\text { Gen } \\
\text { der }\end{array}$ & $\begin{array}{l}\text { Clinical } \\
\text { condi- } \\
\text { tion }\end{array}$ & Date of birth & $\begin{array}{l}\text { Polio } \\
\text { immuni- } \\
\text { zation }\end{array}$ & $\begin{array}{l}\text { Stool } \\
\text { specimens } \\
\text { collected }\end{array}$ & $\begin{array}{l}\text { Typ } \\
\text { e of } \\
\text { vi- } \\
\text { rus }\end{array}$ & $\begin{array}{l}\text { CDC } \\
\text { classification }\end{array}$ \\
\hline & & & & & & & cells $/ \mathrm{mm}^{3}$ \\
\hline & & & & $31 / 07 / 2002$ & & \\
\hline & & & $28 / 08 / 2002$ & & & \\
\hline
\end{tabular}

$\mathrm{A}=$ documented asymptomatic HIV infection; $\mathrm{B}=$ symptomatic HIV infection; $\mathrm{C}=$ symptomatic HIV infection with an AIDS indicator condition; BPN = bronchopneumonia; $\mathrm{G} / \mathrm{E}=$ gastroenteritis; $\mathrm{PCP}=$ Pneumocystis carinii pneumonia; $\mathrm{PTB}$ $=$ pulmonary tuberculosis; $\mathrm{TB}=$ tuberculosis.

The majority of the NPEV group (41 isolates) detected in the stool specimens of the immunodeficient children consisted of 7 coxsackievirus B3 (CBV3), 6 echovirus 11 (ECV11), 5 ECV9, and 3 coxsackievirus A6 (CAV6) isolates. These results were in agreement with findings reported previously by other researchers such as Druyts-Voets (1997), Nairn and Clements (1999) as well as Vivier et al. (2001).

In total, 7 of the 23 stool samples taken from healthy immunocompetent children (the control group) tested positive for EVs after receiving their polio immunization (Table 3). All EVs were typed as PVs using the RE analysis, and the Sabin-specific RT-triplex PCR identified them as Sabin PV vaccine strains. Six of the PV isolates were typed as Sabin PVs type 1 . One of the $7 \mathrm{PV}$ isolates was typed as Sabin PV type 2 and was isolated from one of the healthy babies $48 \mathrm{~h}$ after receiving its OPV immunization at 10 weeks of age. According to the results, PV excretion generally stopped by the end of the second week after each vaccination or the number of PVs in the stool specimens was too low to be detected by the molecular techniques applied. Furthermore, in this study, no PVs could be detected in the stool samples collected from one of the immunocompetent children after the 14th week vaccination, even $48 \mathrm{~h}$ after vaccination. In 2 of the immunocompetent children who had received the 18th month polio vaccination, PVs were detected in the stool samples $48 \mathrm{~h}$ after vaccination, but not in the samples collected on a weekly basis after the last polio vaccination, thus indicating cessation of $\mathrm{PV}$ excretion by these children. These results indicated that the immunocompetent children involved in this study did not excrete PVs for more than a month after each polio vaccination. These findings were in agreement with the results of studies in other parts of the world, in which PV was found to be excreted by healthy children for not more than 2-3 months after vaccine administration (Marker Test Subcommittee and the Japan Live Poliovaccine Research Commission, 1967 and Alexander et al., 1997). 
Table 3.

Isolation of PV vaccine strains from stool specimens of immunocompetent children (the control group)

\begin{tabular}{|c|c|c|c|c|c|}
\hline $\begin{array}{l}\text { Sample } \\
\text { number }\end{array}$ & $\begin{array}{l}\text { Gen- } \\
\text { der }\end{array}$ & $\begin{array}{l}\text { Date of } \\
\text { birth }\end{array}$ & Polio immunizations & $\begin{array}{l}\text { Stool specimens } \\
\text { collected }\end{array}$ & $\begin{array}{l}\text { Typ } \\
\text { e of } \\
\text { vi- } \\
\text { rus }\end{array}$ \\
\hline \multirow[t]{4}{*}{$\begin{array}{l}\text { Nat } \\
05 / 24\end{array}$} & Female & $\begin{array}{l}22 / 05 / 20 \\
03\end{array}$ & 22/05/2003 (at birth) & $24 / 05 / 2003$ (after 48 h) & PV1 \\
\hline & & & & $\begin{array}{l}02 / 06 / 2003 \text { (after } 1 \\
\text { week) }\end{array}$ & PV1 \\
\hline & & & & $\begin{array}{l}\text { 10/06/2003 (after } 2 \\
\text { weeks) }\end{array}$ & - \\
\hline & & & & $\begin{array}{l}\text { 18/06/2003 (after } 3 \\
\text { weeks) }\end{array}$ & - \\
\hline \multirow[t]{4}{*}{$\begin{array}{l}\text { Nat } \\
07 / 03\end{array}$} & & & $\begin{array}{l}03 / 07 / 2003 \text { (at } 6 \\
\text { weeks) }\end{array}$ & 05/07/2003 (after 48 h) & PV1 \\
\hline & & & & $\begin{array}{l}12 / 07 / 2003 \text { (after } 1 \\
\text { week) }\end{array}$ & PV1 \\
\hline & & & & $\begin{array}{l}\text { 19/07/2003 (after } 2 \\
\text { weeks) }\end{array}$ & - \\
\hline & & & & $\begin{array}{l}01 / 08 / 2003 \text { (after } 3 \\
\text { weeks) }\end{array}$ & - \\
\hline \multirow[t]{4}{*}{$\begin{array}{l}\text { Nat } \\
08 / 02\end{array}$} & & & $\begin{array}{l}02 / 08 / 2003 \text { (at } 10 \\
\text { weeks) }\end{array}$ & 04/08/2003 (after 48 h) & PV2 \\
\hline & & & & $\begin{array}{l}\text { 12/08/2003 (after } 1 \\
\text { week) }\end{array}$ & - \\
\hline & & & & $\begin{array}{l}\text { 20/08/2003 (after } 2 \\
\text { weeks) }\end{array}$ & - \\
\hline & & & & $\begin{array}{l}\text { 27/08/2003 (after } 3 \\
\text { weeks) }\end{array}$ & - \\
\hline $\begin{array}{l}\text { Nat } \\
09 / 04\end{array}$ & & & $\begin{array}{l}04 / 09 / 2003 \text { (at } 14 \\
\text { weeks) }\end{array}$ & 06/09/2003 (after 48 h) & - \\
\hline
\end{tabular}




\begin{tabular}{|c|c|c|c|c|c|}
\hline $\begin{array}{l}\text { Sample } \\
\text { number }\end{array}$ & $\begin{array}{l}\text { Gen- } \\
\text { der }\end{array}$ & $\begin{array}{l}\text { Date of } \\
\text { birth }\end{array}$ & Polio immunizations & $\begin{array}{l}\text { Stool specimens } \\
\text { collected }\end{array}$ & $\begin{array}{l}\text { Typ } \\
\text { e of } \\
\text { vi- } \\
\text { rus }\end{array}$ \\
\hline & & & & $\begin{array}{l}\text { 13/09/2003 (after } 1 \\
\text { week) }\end{array}$ & - \\
\hline $\begin{array}{l}\text { Mrsa } \\
06 / 03\end{array}$ & $\begin{array}{l}\mathrm{Fe}-- \\
\text { male }\end{array}$ & $\begin{array}{l}18 / 11 / 20 \\
02\end{array}$ & $\begin{array}{l}02 / 03 / 2003 \text { (at } 14 \\
\text { weeks) }\end{array}$ & $\begin{array}{l}\text { 03/06/2003 (after } 3 \\
\text { months) }\end{array}$ & -- \\
\hline \multirow[t]{4}{*}{$\begin{array}{l}\text { Mrsa } \\
06 / 01\end{array}$} & & & $\begin{array}{l}01 / 06 / 2004 \text { (at } 18 \\
\text { months) }\end{array}$ & 03/06/2004 (after $48 \mathrm{~h}$ ) & PV1 \\
\hline & & & & $\begin{array}{l}\text { 10/06/2004 (after } 1 \\
\text { week) }\end{array}$ & - \\
\hline & & & & $\begin{array}{l}\text { 17/06/2004 (after } 2 \\
\text { weeks) }\end{array}$ & - \\
\hline & & & & $\begin{array}{l}\text { 24/06/2004 (after } 3 \\
\text { weeks) }\end{array}$ & - \\
\hline Ln 06/09 & Male & $\begin{array}{l}10 / 12 / 20 \\
01\end{array}$ & $\begin{array}{l}\text { 24/03/2002 (at } 14 \\
\text { weeks) }\end{array}$ & $\begin{array}{l}\text { 09/06/2003 (after } 15 \\
\text { months) }\end{array}$ & - \\
\hline \multirow[t]{3}{*}{$\operatorname{Ln} 06 / 17$} & & & $\begin{array}{l}17 / 06 / 2003 \text { (at } 18 \\
\text { months) }\end{array}$ & 19/06/2003 (after $48 \mathrm{~h}$ ) & PV1 \\
\hline & & & & $\begin{array}{l}\text { 22/06/2003 (after } 1 \\
\text { week) }\end{array}$ & - \\
\hline & & & & $\begin{array}{l}\text { 30/06/2003 (after } 2 \\
\text { weeks) }\end{array}$ & - \\
\hline
\end{tabular}

In 8 of the immunodeficient children (P020, P025, P031, P039, P045, P069, P114, and P126), PVs were detected in stool specimens collected less than 3 months after their last polio immunization (Table 2). Patient P114 (6-month-old baby) was immunized at the age of 14 weeks, and Sabin PV type 1 was detected in a stool specimen collected 3 months after the last recorded vaccination. Patients P025 (18-month-old baby) and P126 (20-month-old baby) were immunized at 18 months of age. PVs type 3 were detected in stool samples collected from both patients 2 weeks (for P025) and 2 months (for P126) after the last polio vaccination (Table 2). In comparison to these immunodeficient patients, OPV strains could not be detected in the current study in stool samples of the immunocompetent children collected after the 14th week vaccination and a week after the 18th month vaccination. Patient P045 (4-month-old baby) was immunized lastly at 6 
weeks of age and tested positive for PV type 3 a month after vaccination. A second follow-up stool sample, collected from patient P045, tested negative for PV 3 months after the last polio vaccination (at the age of 6 weeks), indicating a possible cessation of PV excretion by this patient. Patient P045 was admitted to the hospital for pneumonia and had $\mathrm{CD}^{+}$counts between 200 and 499 cells $/ \mathrm{mm}^{3}$. In general, there was a lack of a complete record in the polio immunization schedule for several of the immunodeficient patients, because most of them could not visit the hospital for routine immunization or have omitted immunization dates for various unknown reasons, and therefore, the excretion of OPV strains by these patients could not be monitored throughout the whole study. Thus, it is not certain whether patients P020, P031, P039, P045, and P069 have received a 10th and a 14th week polio vaccination due to the lack of a complete vaccination record.

In this study, stool specimens collected from 2 of the immunodeficient children (P085 and P095) tested positive for OPV strains approximately 7 months after the last recorded polio vaccination. Patient P085 (1-year-old baby) was immunized at the age of 14 weeks, and Sabin PV type 1 was detected in a stool specimen collected 7 months after the last polio vaccination. This baby was hospitalized for pneumonia and marasmus and presented with $\mathrm{CD}^{+}$counts of less than 200 cells $/ \mathrm{mm}^{3}$. Patient P095 (2-year-old child) was lastly immunized at the age of 18 months, and Sabin PV type 1 was detected in a stool specimen collected 7 months after this last polio vaccination. The patient was hospitalized for chronic diarrhea and also had CD4 ${ }^{+}$counts of less than 200 cells $/ \mathrm{mm}^{3}$. Since immunocompetent children are known to excrete OPV strains for up to 3 months after vaccination (Alexander et al., 1997), the excretion of OPV strains by the immunodeficient children (P085 and P095) in this study could be considered as prolonged.

Prolonged excretion of OPV strains for more than 15 months was observed in 2 other immunodeficient children (P023 and P140) involved in this study (Table 2). Patient P023 (18-month-old baby) had his last recorded OPV immunization at the age of 14 weeks, and a stool specimen taken 15 months later tested positive for Sabin PV type 3. The other patient (P140, a 19-month-old baby) had his last recorded OPV immunization at 14 weeks, and a stool specimen taken 16 months later tested positive for Sabin PV type 1. Both of these children had CD4 $4^{+}$counts between 200 and 499 cells $/ \mathrm{mm}^{3}$ and were hospitalized for various diseases such as encephalopathy, gastroenteritis, pulmonary tuberculosis, and pneumonia. A 5-year-old child (patient P052) who had received her last polio immunization at the age of 18 months tested positive for Sabin PV type 1, which was more than 42 months after the stool specimen was collected. Patient P052 had CD $4{ }^{+}$ counts of less than 200 cells $/ \mathrm{mm}^{3}$ and was hospitalized with miliary tuberculosis. Since patient P052 was 5 years old, the last polio vaccination date according to the immunization schedule should have been on the 2003 September 26; however, the last stool sample was collected before the child was due for vaccination. Thus, based on the immunization records, this case represented the most prolonged period of OPV excretion by an immunodeficient patient in this study, which may have important implications regarding the control of health risks constituted by OPV vaccination, particularly with regard to immunodeficient patients. 
Based on these results, it can be concluded that immunodeficient patients have the potential to excrete PVs for a prolonged period, and therefore, these patients may serve as potential reservoirs for the reintroduction of PVs in the posteradication era. However, this prolonged excretion cannot definitely be attributed to the vaccine alone since there is the possibility of person-to-person transmission as well as acquiring PVs from the environment. Live vaccines should never be given to immunodeficient patients, in their own interest and in the interest of the community. However, even if these patients have received OPV before the deficiency is diagnosed, strict monitoring will not prevent person-to-person contact and/or reinfection.

\section{Conclusion}

Although this study could not present a definitive hard evidence for long-term excretion of PVs in HIV-positive children, one important conclusion that can be made from the results is that HIV-positive children seem to be more susceptible to viral infections than other healthy children. As a next step, the genomes of the OPV strains isolated from the immunodeficient as well as from the immunocompetent children will be sequenced to find any possible mutations leading to increased neurovirulence of these vaccine strains (VDPVs). Data on the excretion of VDPVs by carrier communities (notably immunodeficient individuals) will give an indication of the quantitative release of these strains into the environment and the potential health risk they might constitute. This information would be essential for strategies aimed at the protection of newly born children who are no longer being vaccinated during the posteradication era as well as protecting immunodeficient patients against complications of OPV vaccination such as acute flaccid paralysis.

\section{References}

Alexander et al., 1997 J.P. Alexander Jr, H.E. Gary Jr and M.A. Pallansch, Duration of poliovirus excretion and its implications for acute flaccid paralysis surveillance: a review of the literature, J. Infect. Dis. 175 (1997), pp. S176-S182.

Bellmunt et al., 1999 A. Bellmunt, G. May, R. Zell, P. Pring-Akerblom, W. Verhagen and A. Heim, Evolution of poliovirus Type I during 5.5 years of prolonged enteral replication in an immunodeficient patient, Virology 265 (1999), pp. 178-184.

Buttinelli et al., 2003 G. Buttinelli, V. Donati, S. Fiore, J. Marturano, A. Plebani, P. Balestri, A.R. Soresina, R. Vivarelli, F. Delpeyroux, J. Martin and L. Fiore, Nucleotide variation in Sabin type 2 poliovirus from an immunodeficient patient with poliomyelitis, J. Gen. Virol. 84 (2003), pp. 1215-1221.

Centers for Disease Control and Prevention, 1997 Centers for Disease Control and Prevention, Prolonged poliovirus excretion in an immunodeficient person with vaccine- 
associated paralytic poliomyelitis, MMWR Morb. Mortal. Wkly. Rep. 46 (1997), pp. 641643.

Centers for Disease Control and Prevention, 2003 Centers for Disease Control and Prevention, Progress toward poliomyelitis eradication-Southern Africa, 2001-March 2003, MMWR Morb. Mortal. Wkly. Rep. 52 (2003), pp. 521-524.

Chitsike and van Furth, 1999 I. Chitsike and R. van Furth, Paralytic poliomyelitis associated with live oral poliomyelitis vaccine in a child with HIV infection in Zimbabwe: case report, BMJ 318 (1999), pp. 841-843.

Druyts-Voets, 1997 E. Druyts-Voets, Epidemiological features of entero non-polio isolations in Belgium 1980-1994, Epidemiol. Infect. 119 (1997), pp. 71-77.

Egger et al., 1995 D. Egger, L. Pasamontes, M. Ostermayer and K. Bienz, Reverse transcription multiplex PCR for differentiation between polio- and enteroviruses from clinical and environmental samples, J. Clin. Microbiol. 33 (1995), pp. 1442-1447.

Gow et al., 1991 J.W. Gow, W.M.H. Behan, G.B. Clements, C. Woodall, M. Riding and P.O. Behan, Enteroviral RNA sequences detected by polymerase chain reaction in muscle of patients with postviral fatigue syndrome, BMJ 302 (1991), pp. 692-696.

Hovi et al., 2004 T. Hovi, N. Lindholm, C. Savolainen, M. Stenvik and C. Burns, Evolution of wild-type 1 poliovirus in two healthy siblings excreting the virus over a period of 6 months, J. Gen. Virol. 85 (2004), pp. 369-377.

Ion-Neldescu et al., 1994 N. Ion-Neldescu, A. Dobrescu, P.M. Strebel and R.W. Sutter, Vaccine-associated paralytic poliomyelitis and HIV infection, Lancet 343 (1994), pp. 5152.

Kämmerer et al., 1994 U. Kämmerer, B. Kunkel and K. Korn, Nested polymerase chain reaction for specific detection of and rapid identification of human picornaviruses, $J$. Clin. Microbiol. 32 (1994), pp. 285-291.

Kew et al., 1998 O.M. Kew, R.W. Sutter, B.K. Nottay, M.J. MacDonough, D.R. Prevots, L. Quick and M.A. Pallansch, Prolonged replication of a type 1 vaccine-derived poliovirus in an immunodeficient patient, J. Clin. Microbiol. 36 (1998), pp. 2893-2899.

Kuan, 1997 M.M. Kuan, Detection and rapid differentiation of human enteroviruses following genomic amplification, J. Clin. Microbiol. 35 (1997), pp. 2598-2601.

Manor et al., 1999a Y. Manor, R. Handsher, T. Halmut, M. Neuman, B. Abramovitz, A. Mates and E. Mendelson, A double-selective tissue culture system for isolation of wildtype poliovirus from sewage applied in a long term environmental surveillance, Appl. Environ. Microbiol. 65 (1999), pp. 1794-1797. 
Manor et al., 1999b Y. Manor, R. Handsher, T. Halmut, M. Neuman, A. Bobrov, H. Rudich, A. Vonsover, L. Shulman, O.M. Kew and E. Mendelson, Detection of poliovirus circulation by environmental surveillance in the absence of clinical cases in Israel and the Palestinian authority, J. Clin. Microbiol. 37 (1999), pp. 1670-1675.

Marker Test Subcommittee and the Japan Live Poliovaccine Research Commission, 1967 Marker Test Subcommittee, the Japan Live Poliovaccine Research Commission, Evaluation of Sabin live poliovirus vaccine in Japan, IV-Marker tests on poliovirus strains recovered from vaccinees and their contacts, Jpn. J. Med. Sci. Biol. 20 (1967), pp. $167-173$.

Melnick, 1996 J.L. Melnick, Enteroviruses: polioviruses, coxsackieviruses, echoviruses and newer enteroviruses. In: B.N. Fields, D.M. Knipe and P.M. Howley et al., Editors, Fields Virology (3rd ed.), Lippincott-Raven, Philadelphia, PA (1996), pp. 655-712.

Minor, 1999 P.D. Minor, Poliovirus vaccination: current understanding of poliovirus interactions in humans and implications for the eradication of poliomyelitis, Exp. Rev. Mol. Med. (1999)http://www-ermm.cbcu.cam.ac.uk.

Minor, 2001 P.D. Minor, Biosafety consequences of eradication of wild-type polioviruses, Lancet 358 (2001), pp. 166-168.

Nairn and Clements, 1999 C. Nairn and G.B. Clements, A study of enterovirus isolations in Glasgow from 1977-1997, J. Med. Virol. 58 (1999), pp. 304-312.

Shulman et al., 2000 L.M. Shulman, J. Manor, R. Handsher, F. Delpeyroux, M.J. MacDonough, T. Halmut, I. Silberstein, J. Alfandari, J. Quay, T. Fisher, J. Robinov, O.M. Kew, R. Crainic and E. Mendelson, Molecular and antigenic characterisation of a highly evolved derivative of the type 2 oral poliovaccine strain isolated from sewage in Israel, J. Clin. Microbiol. 38 (2000), pp. 3729-3734.

Sutter and Prevots, 1994 R.W. Sutter and D.R. Prevots, Vaccine-associated paralytic poliomyelitis among immunodeficient persons, Infect. Med. 11 (1994), pp. 426-438.

Triki et al., 2003 H. Triki, M.R. Barbouche, O. Bahri, M. Bejaoui and K. Delllagi, Community-acquired poliovirus infection in children with primary immunodeficiencies in Tunisia, J. Clin. Microbiol. 41 (2003), pp. 1203-1211.

Vivier et al., 2001 J.C. Vivier, C.G. Clay and W.O.K. Grabow, Detection and rapid differentiation of human enteroviruses in water sources by restriction enzyme analysis, Wat. Sci. Technol. 43 (2001), pp. 209-212.

World Health Organization Scientific Group, 1997 World Health Organization Scientific Group, Primary immunodeficiency diseases, Clin. Exp. Immunol. 109 (1997), pp. 1-28. 
Wood et al., 2000 D.J. Wood, R.W. Sutter and W.R. Dowdle, Stopping poliovirus vaccination after eradication: issues and challenges, Bull. World Health Organ. 78 (2000), pp. 347-357.

Wood and Thorley, 2003 N. Wood and B. Thorley, Viewpoint towards global poliomyelitis eradication: the successes and challenges for a developed country, $J$. Paediatr. Child Health 39 (2003), pp. 647-650.

Yang et al., 1991 C.-F. Yang, L. De, B.P. Holloway, M.A. Pallansch and O.M. Kew, Detection and identification of vaccine-related polioviruses by the polymerase chain reaction, Virus Res. 20 (1991), pp. 159-179.

Yang et al., 1992 C.-F. Yang, L. De, S.-J. Yang, J.R. Gòmez, J.R. Cruz, B.P. Holloway, M.A. Pallansch and O.M. Kew, Genotype-specific in vitro amplification of sequences of the wild type 3 polioviruses from Mexico and Guatemala, Virus Res. 24 (1992), pp. 277296.

Yang et al., 2003 C.-F. Yang, T. Naguib, S.-J. Yang, E. Nasr, J. Jorba, N. Ahmed, R. Campagnoli, H. van der Avoort, H. Shimizu, T. Yoneyama, T. Miyamura, M. Pallansch and O. Kew, Circulation of endemic type 2 vaccine-derived poliovirus in Egypt from 1983-1993, J. Virol. 77 (2003), pp. 8366-8377.

Zaoutis and Klein, 1998 T. Zaoutis and J.D. Klein, Enterovirus infections, Pediatr. Rev. 19 (1998), pp. 183-191. 